Arch. histol. jap. Vol. 21, n. 4-5 (May 1961). P. 535-544.

First Dept. of Anat. (Prof. M. MORI), Fac. of Med., Kyushu Univ., Fukuoka, Japan.

\title{
Appearance of Hemoglobin in the Earliest Erythroblast.
}

\author{
初期赤芽球に於け乃へモグロビンの出现像.
}

\section{Masayuki MIYOSHI 三妒萬佐行.}

(Received May 18, 1961.)

Cytochemical studies on the biosynthesis of hemoglobin have generally been carried ont by detecting it in the earlier erythropoietic cells of each developmental stage from the view poit of its commencement, localization and activity.

There was formerly an opinion of LOELE (1910), VILLA (1930) and KNOLL (1931), nuclear theory of hemoglobin synthesis, which was drawn from the purely morphological findings that nuclear acidophilia of the earlist cells was accomplished at the basophilic erythroblast stage developed from the blood stem cells, while the cytoplasm, entirely basophilic at the stage, manifested polychromatophilia by way of perinuclear acidophilia and at last became completely acidophilia.

Some of the histochemists, SLONIMSKI (1936) and so forth, investigated the peroxidase reaction belonging to hemoglobin and found that in cytoplasm and nucleus of erythroblast in the circulating blood of amphibian embryo the reaction of peroxidase was generally positive, but in some of the erythroblasts only the nucleus had its positive reaction. And they arrived at the same conclusion.

On the other hand, SORET (1878) studied on the monochromatic absorption of the biological substances and found the specific band in the absorption of heme and its compounds, he named it Soret band. According to COLE and BRACKETT(1940), this Soret band has the same pattern of heme absorption in cell and solution.

BRACKETT and DUSTIN stated that RNA (ribonucleic acid) might take parts in the formation of hemoglobin, and CASPERSSON suggested that the RNA had relationship to the protein synthesis. Those two conceptions allowed THORELL (1947) to achieve the brilliant attribution to hematology. He used monochromatic light ( $436 \mathrm{~m} \mu$ for Oxyhemoglobin, $406 \mathrm{~m} \mu$ for heme and $260 \mathrm{~m} \mu$ for RNA) to research the juvenile forms of red blood cell in their different phases of maturation, and suggested that hemoglobin could be already in the cytoplasm of basophilic erythroblast, and RNA, much abundant at the growth period, decreased in inverse propotion to the accumulation of hemoglobin (means the cellular differentiation) and the greatest potentiality of hemoglobin synthesis was found at the polychromatic phase.

If all proteins, including ones of hemoglobin, are mainly produced in cytoplasm in co-operation with the cellular development, the problems which remain to be solved are which cellular particles do the formation of heme, prosthetic group, and its combination with the globin protein. And how should be interpreted the intranuclear hemoglobin of earlier erythroblast which was reported by many authors? 
We know great attributions to the series of biochemical investigation which was focused to search the potential organelles to synthesize the heme and its compounds. With autoradiographic results (NAKAO and NAGI 1958) that $\mathrm{Fe}^{59}$ was incoporated to heme in the nucleus of the earlist erythroblasts, they assumed that nucleus of the cell of the earlist erythropoitic series has the role of hemoglobin synthesis. In order to support that conception, they examined the heme absorption of the series of erythroid cells and found the cells having the absorption at Soret band in the nucleus only. WALSH (1941), JENSEN (1953) and THORELL (1953) reported that nonnucleted erythroblast, reticulocyte, had an ability to produce hemoglobin. SENO $(1957,1958)$ recognized the mitochondria in the reticulocyte with reticular structures as endoplasmic reticulum, and he suggested that synthesis of hemoglobin proceeded most actively in the reticulocyte atage. He also referred no evidence of intranuclear production of hemoglobin.

SANO (1955) discovered mitochondria in basophilic stippled cell of peripheral blood of maus poisened with lead, and confirmed that mitochondria played great important role to the metabolism of porphyrin and heme compounds (1958).

Not speaking of authors who stood to the intranuclear theory of hemoglobin synthesis, however, even all the investigators, who claimed the cytoplasmic stemming of hemoglobin, have similarly described that the hemoglobin appeared in the nucleus of early cell of the erythroid series. As showed definitely by WILKINS and CARVALHO (1953) and CARVALHO (1953) with cytochemical (RALPH's and leuco dye stain methods for hemoglobin) and phase contrast microscopical techniques and by CARVALHO (1955) with michrospectrographical method, the intranuclear hemoglobin is demonstrated under the forms of granulation and considered that it was localized among the meshes of the chromatin net work. But no one has reported the diffusal picture of hemoglobin in the nucleus.

As mentioned above, the quetion of origin of the intranuclear hemoglobin remains still to be not decisively solved, if all hemoglobin were formed in the cytoplasm. METCALF, too, referred the requirrance of further investigation on it. Resuming from the above mentioned reports, I summarized that there were two theories on the formation of intranuclear hemoglobin in the erythroblast, namely as follow: 1. THORELL assumed that the hemoglobin in the nucleus might be thing which had been taken into the nucleus by its adhering to the chromosomes at mitosis. 2 . SENO (1958) researched the permeability of nucleus menbrane of erythroblast by using his original supravital stainning with Nile blue solution and successed to get pictures which evidently indicated that the nucleus of erythroblast had such an increased permeability to the dye like those of dead cells. He decided that intranuclear hemoglobin might be immigrated from the cytoplasm into the nucleus.

In consequence of those, a few of question occurred to me. If production of hemoglobin is limited to the cytoplasm, may hemoglobin be detected in the cytoplasm alone of the numbers of proerythroblast, because METOCALF detected hemoglobin in the proerythroblast?

Are we able to find commonly such cases as the absorption of heme limited to the nucleus of basophilic erythoblast, as showed by SLONIMSKI and NAGAI, or as the absorption has stronger intensity in whether the cytoplasm or the nucleus of the 
earlist erythropoietic cell?

Therefore, in order to make clear these questions, I have carried out this investigation observing the extravascular hematopoiesis of yolk sac of chicken embryo, where cells at almost same degree of each developmental stage can be obtained relatively in much numbers at the small destrict and time factor can be voluntarily controlled.

\section{Materials and Methods.}

After the eggs of white leghorn had been incubated at $39 \pm 0.5^{\circ} \mathrm{C}\left(\right.$ about $100^{\circ} \mathrm{F}$ ), the primitive blood islands were removed from the vascular area of germinal zone of the yolk sack with a iridectomy pincette and the blood was obtained from the extra embryonal vessels, in which the blood circulation just begun.

These materials smeared on quarz slide glasses were treated with formol vapour for 24 hours and fixed with methanol, by these procedures all hemoglobin turned to met-hemoglobin and the blood cells could not be broken in glycerin immersion.

The heme absorption was photographed in a monochromatic light $(408 \mathrm{~m} \mu)$ from the super high pressure mercury lamp (UV. microscope: Model MBO Olympus was used).

Hemoglobin was stained by RALPH's method.

GIEMSA's and MAY-GRUENWALD-GIEMSA's method were applicated for determining the developmental stage of erythropoietic cells.

\section{Results.}

Primitive blood cells (Fig. 1 and 4). These cells are very voluminous (average diameter, $27 \mu$ ) and are mostly able to be obtained from about 30 hours and over incubated embryos and generally appear in groups near the accumulations of mesoblastic elements.

They are easily distinguished from increasing their distinct acidophilia of the nuclei and basophilia of the cytoplasm. Although some of primitive blood cells have small protuberances like bubbling of cytoplasm and they seem as if the cytoplasm were fused each other, the primitive blood cells are mostly round in shape, and the cytoplasm with very plentiful vacuoles, which fill large parts of the cells closing the less matured, is perfectly basophilic. A definitely acidophilic nucleus is very large and has clearly visible fine chromatin, and some nucleoli are all of a lump and stained with condense red-violet. However, there is no granulated feature which commonly arises in the chromatin net work of more matured cells (basophilic megaloblast).

These cells were negative to cytochemical method for hemoglobin and heme absorption in Soret band.

Promegaloblasts (Fig. 2 and 5). In about 35-45 hours incnbated embryos, it can be made out with naked eye to observe that more large and whitish primitive blood islands are put in a chain surroundig the peripheral zone of vascular area. At this period, some islands, mostly consisting of promegaloblasts, are noticed in the 


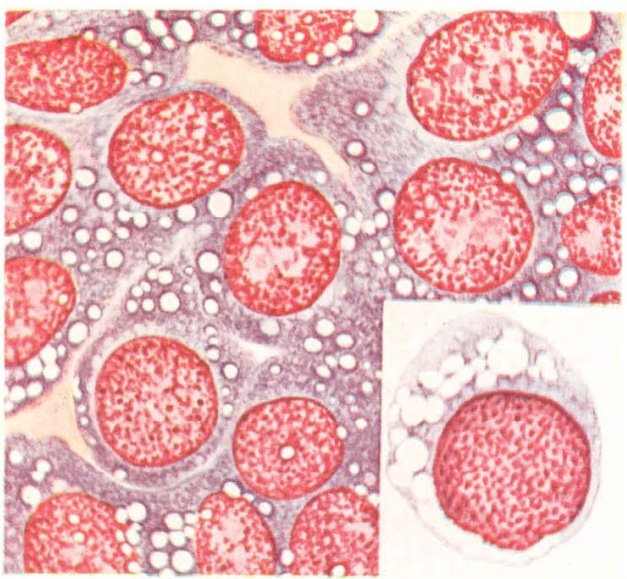

Fig. 1. Primitive blood cells. One of them is pictured in detail at the right under corner. These cells have very voluminous cell bodies and very prentiful vacuoles in the basophilic cytoplasm. Some nucleoli make one or two groups in the fine chromatin. The nuclei are acidophilic. (GIEMSA's stain)
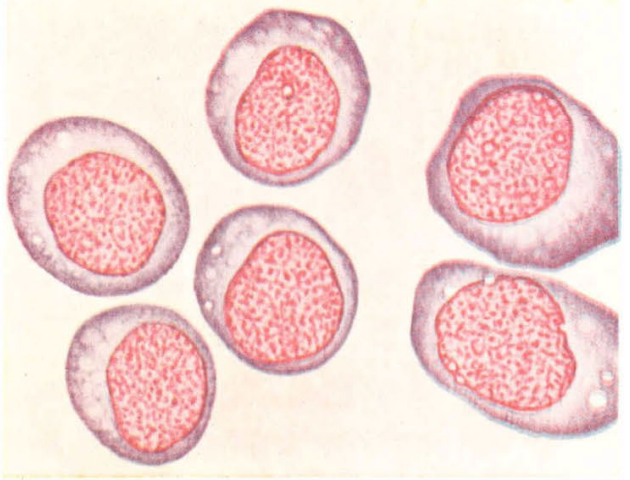

Fig. 2. Promegaloblasts. These cells are still voluminous and have conciderable vacuoles in the cytoplasm, which is stained in much strengthened basophilia. Chromatin is acidophilic and shows the fine net work. (GIEMSA's stain)

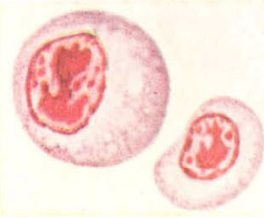

Fig. 3. Basophilic megaloblasts. These cells ditinguish themselves from their spherical cell bodies and the equolly basophilic cytoplasm without vacuole. Many granules in the nucleus are stained in condense colour of red violet. (GIEMSA's stain) characteristic colour of hemoglobin under the magnifying lense.

By comparing with the former, promegaloblastic elements became somewhat smaller in size and more round in shape, but still voluminous (about $20 \mu$ ) and slightly irregular in contuor. Considerable numbers of vacuole are retained still in the basophilic cytoplasm, the peripheral zone of which is stained darker than the perinuclear zone. The cytoplasm appears as the narrow zonal profile, with reasons, I suppose, that numerous vacuoles have been rapidly superseded with cytoplasmic substances and the nucleus retains the similar size to the nucleus of primitive blood cell.

A few nucleoli become more conspicuous for their increased basophilia and shrpness of individual contour in the fine chromatin.

The heme absorption at monochromatic light $(408 \mathrm{~m} / \mu)$ can be significantly photographed at the cytoplasmic region (Fig. 7 ) and the same result is obtained even by the cytochemical technique, RALPH's stain method for hemoglobin (Fig. 8). Both these pictures indicate decisively the diffusal formation of hemoglobin in the cytoplasm, but never its granulated existence within the nucleus of cells at this developmental atage.

Basophilic megaloblasts (Fig. 3 and 6). At the developmental stage, when the blood circulation begins in about 55 hours and easily can be seen in about 60 hours incubated embryos, the most diffe- 
rentiated cell of the erythroid series is megaloblast. The degree of its maturation distinguishes itself from its spherical cell body with sharp contour, substantality of the complete basophilic cytoplasm and its missing fineness of the chromatin nets work. Although some cells have unmatured style of the cytoplasm like those of promegaloblasts in the extravascular blood forming area, the vacuoles are nearly disappeared and the cytoplasm is completely filled with the equally basophilic sulstance. Acidophilia still remains in the nucleus, in which chromatin loses its fineness and many condense granulations arise among the meshes of chrmatin net work. The contrast between the nucleus and the cytoplasm is then very clear, but the nucleoli are not so.

The heme absorption in Soret band $(408 \mathrm{~m} / \mu)$ (Fig. 9) is very much increased at the whole cytoplasmic region with diffuse manifestation. And also the nucleus gives the heme absorption and its absorption picture is remarkable for such a feature that many granules in nearly similar size lie scatterd throughout the nucleus, but one or two small roud parts in the nucleus have no absorption. I think that those parts may be nucleoli. In the cells of this developmental stage the intranuc'ear absorption of heme appears at first with granular form. These results can be obtained from the cytochemical procedure (Fig. 10).

As to the pictures of mitosis (Fig. 11), the heme absorption localizing in sites of chromosomes

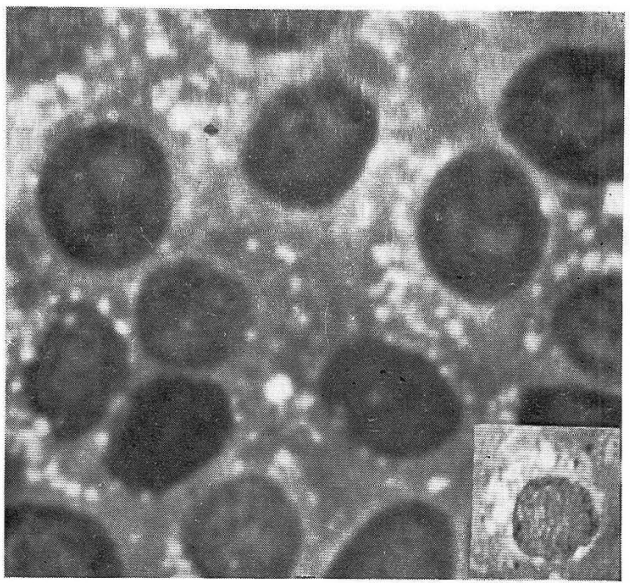

Fig. 4. Primitive blood cells. Photograph of Fig. 1.

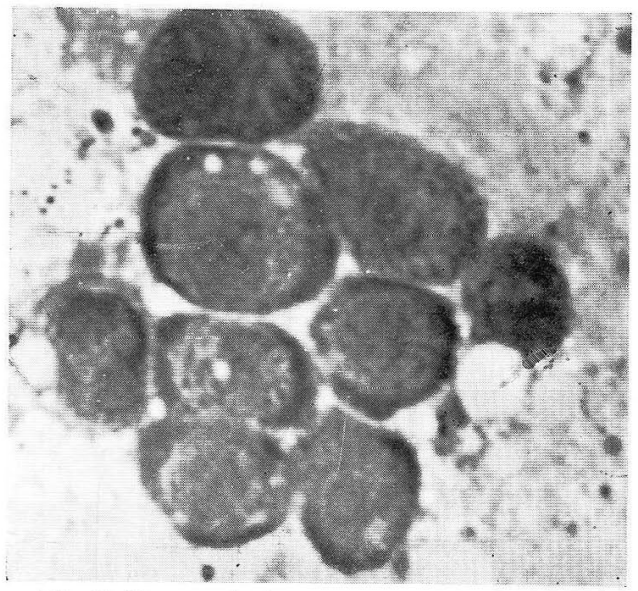

Fig. 5. Promegaloblasts. Photograph of Fig. 2.

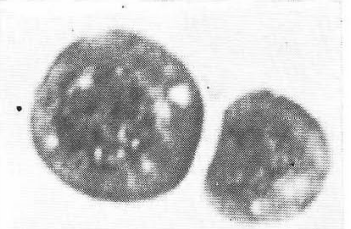

Fig. 6. Basophilic megaloblasts. Photograph of Fig. 3. 


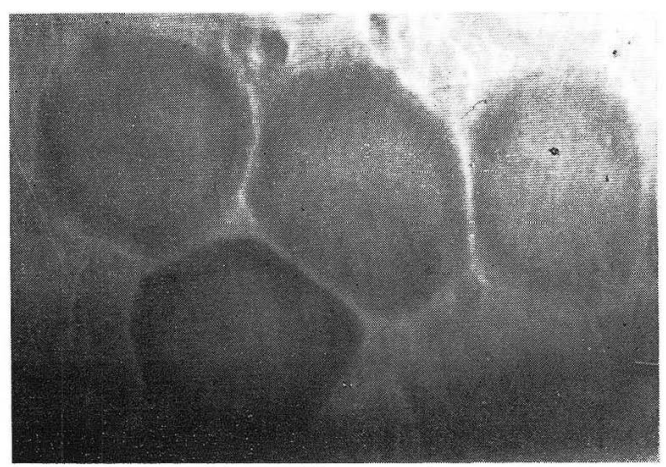

Fig. 7. Promegaloblasts (photographed in a spectrum, $408 \mathrm{~m} \mu$ ). Significant absorption of heme is indicated in the cytoplasm, but there is no such a granulated absorption in the nucleus that appears at first in the nucleus of basophilic megaloblast.

Fig. 8. Promegaloblasts (stained with RALPH's method. Hemoglobin is localized in the cytoplasm alone and is not stained in the nucleus.
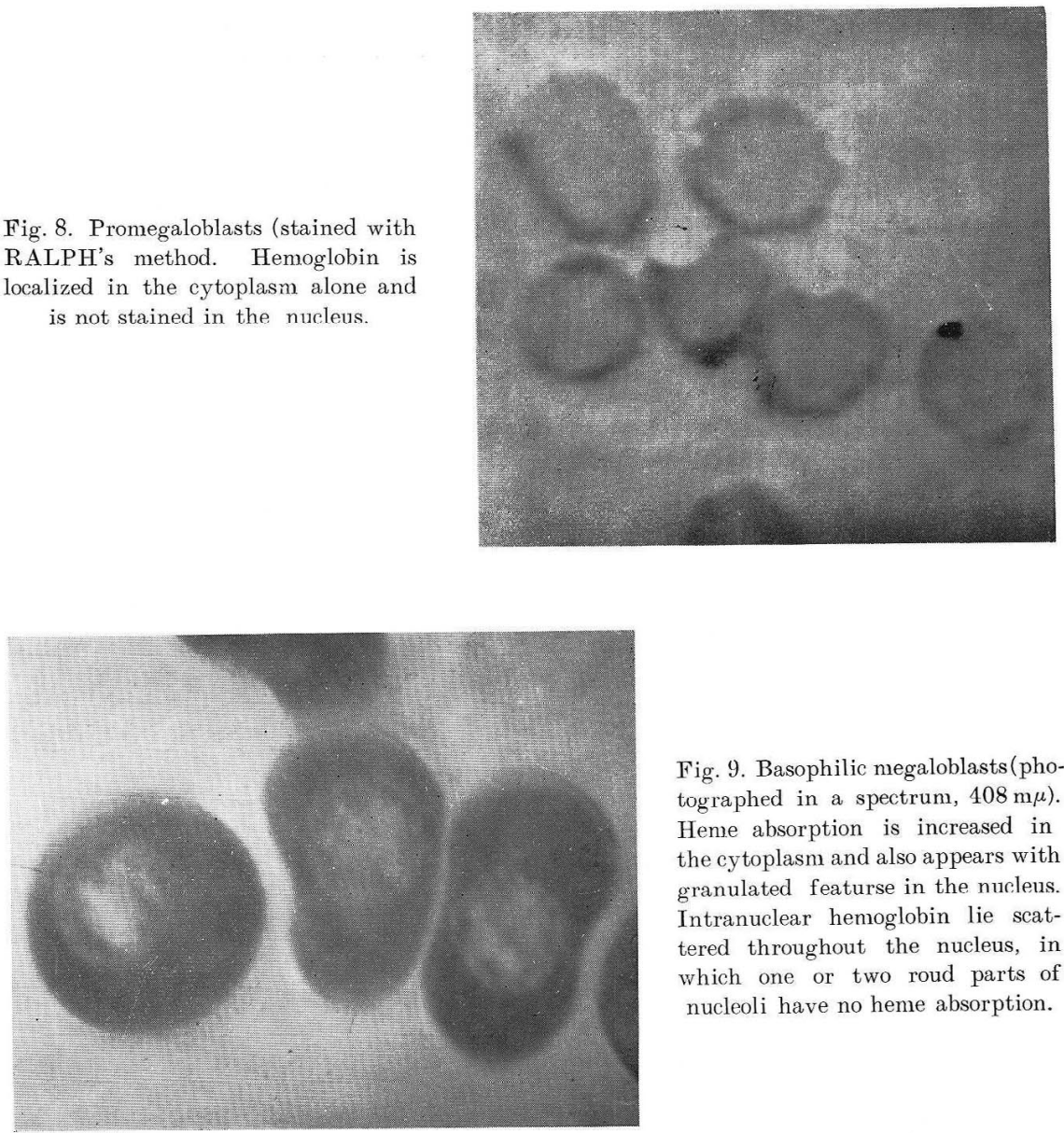

Fig. 9. Basophilic megaloblasts (photographed in a spectrum, $408 \mathrm{~m} \mu$ ). Heme absorption is increased in the cytoplasm and also appears with granulated featurse in the nucleus. Intranuclear hemoglobin lie scattered throughout the nucleus, in which one or two roud parts of nucleoli have no heme absorption. 


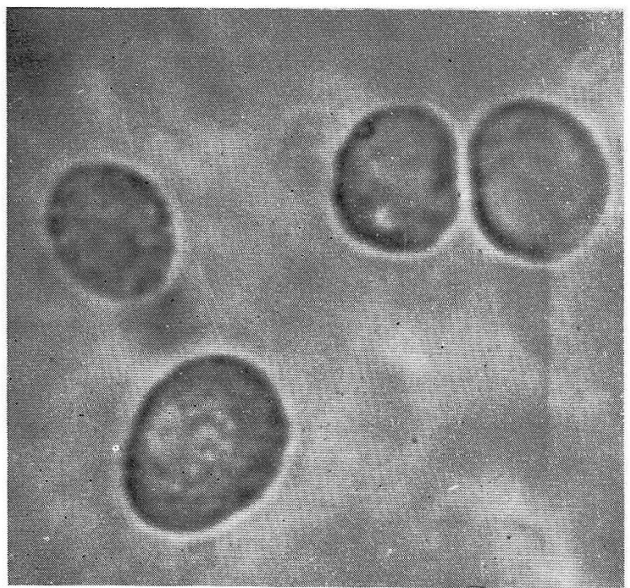

Fig. 10. Basophilic megaloblasts (stained with RALPH's method). This picture shows the same results that the absorption of heme is photographed in the cell of basophilic megaloblast stage.

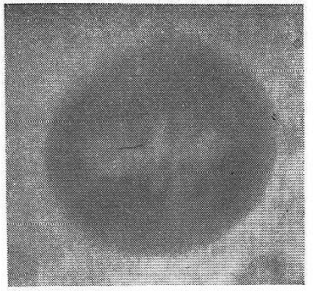

Fig. 11. Basophilic megaloblast in anaphase of cell division (photographed in a spectrum, $408 \mathrm{~m} \mu$ ). There are granulated absorptions of heme localizing the sites of chromosomes.

at the anaphase of cell division is stronger than in the rest of cytoplasm and has the similar granulated features like those in the rest-phase.

With the fact that the hemoglobin increases rapidly its concentration in the nuclei of cclls of the basophilic megaloblast phase, this figure of mitosis suggestes that some of the hemoglobin may be taken into the nucleus by means of its adhering to the chromosomes or interchromosome spaces.

\section{Discussion and Conclusion.}

They say that the biood forming cells proliferate with rhythm. According to ASTALDI and his co-workers (1953), they studied on the proliferation rhythm of primitive embryonic erythroblasts in yolk sack of chicken and summerized that such a proliferation was not synchronous, but governed by the law of fluctuating variability. However, it can be easily asserted that the primitive embryonic erythroblasts proliferate and mature as a function of time factor, if fresh eggs are incubated at the same temperature and humidity.

This was so sufficient and convenient to search some numbers of erythropoietic cell at a certain devclopmental stage under a microscopy, because the great number of them smeared on the same slide glass stood for either case of the series of erythropoiesis. STOLTI (1935) morphologically classified it (quoted by ASTALDI) as following: indifferent mesodermal cell $\rightarrow$ indifferent mesoblast $\rightarrow$ primitive blood cell $\rightarrow$ promegaloblast $\rightarrow$ basophilic megaloblast.

Most of cells in the blood islands are erythropoietic as reported by SABIN (1920).

And in the beginning of circulation, where is not obvious the morphological affection (means the appearance of secondary erythroblast) on the blood forming 
cells by embryo itself, there were a small number of embryonic leucocyte. These leucocytes have been estimated by AMANO and his co-workers as cells surrounding the each blood island before the commencement of circulation.

In the observation of the pictures of heme absorption at $408 \mathrm{~m} \mu$ spectrum, promegaloblasts in blood islands of the yolk sack of the chicken embryo show obviously that there is very dilute concentration of heme in the cytoplasm. But SENO and CARVALHO denied the heme absorption in the cell of proerythroblastic stage.

If it is true that in earlier erythroblast the commencement of globin synthesis may precede that of heme formation and that mitochondria play a important role in each process of the biosynthesis of heme and hemoglobin, the above finding is convincible, since globin protein can be detected already in the cytoplasm of proerythroblast and also SORENSON (1961) recognized the existence of many mitochondria in the blood stem cells. In addition to it, I demonstrated the presence of hemoglobin in promegaloblasts by the cytochemical method, RALPH's stain method.

The heme absorption and hemoglobin stainning are positive in the cytoplasm, but negative in the nucleus. Although it must be reasonably so dangerous to deny the intranuclear hemoglobin from only these results, it is not excessive to say that there is no such a grannlated hemoglobin among the meshes of the chromatin net work that all authors have described as to intranuclear hemoglobin.

At the following stage of maturation, heme absorption and cytochemical activity increase their intensities in the cytoplasm and appear in the nucleus, in which the absorption pictures are very characteristic granules, and these granules lie scattered throughout the nucleus except the site of nucleoli.

In observation on each developmental stage from primitive blood cell to basophilic megaloblast, such a cell that heme absorption limited to the nucleus or was significantly stronger in the nucleus than in the cytoplasm has never been found as in the case of SENO and his co-workers. Therefore, I am very doubtful of the conception of NAKAO and NAGAI that the heme formation is taken place in the nucleus of earlier erythroblast and the faculty of heme production is removed to the cytoplasm at later stages.

As described in the introduction, SENO has suggested that intranuclear hemoglobin might be caused by its immigration through the nuclear membrane. Granted that it is true, what kind of kraft is that that makes such large cytoplasmic molecule as hemoglobin immigrate into the nucleus, where RNA is still vegorausly immigrating from nucleus to cytoplasm?

No matter that there has been obtained no decisive evidence to deny the permeability of nuclear membrane to the nuclear direction, I will want to agree with THORELL, because the mitotic period is only one chance to allow the chromatin substance to be directly in the cytoplasmic, and the granules of hemoglobin which were localizing in the sites of chromosomes were photographed by me at the anaphase of cell division.

\section{Summery.}

The author examined the appearance of hemoglobin in the earlier cells of the erythroid series in the extravascular blood forming areas, primitive blood islands, 
and the blood in the primitive blood vessels at the yolk sack of chicken embryo.

Applicated techniques were 1. GIEMSA'S and MAY-GRUENWALD-GIEMSA'S stains for determinating the developmental stages of cells, 2. microspectrography to research the heme and RNA absorptions and 3. RALPH's stain method to indicate the hemoglobin.

1. Primitive blood cells indicated no heme absorption and hemoglobin activity.

2. Promegaloblast had considerable vacuoles in the cytoplasm, which showed significantly the diffusal heme absorption and hemoglobin activity. But their granulated pictures which were characteristic to the intranuclear hemoglobin were not found in the nuclei of cells at this stage. Then, hemoglobin may be chiefly produced in the cytoplasm of erythroblast.

3. The intensity of both hemoglobin activity and heme absorption were so increased in the cytoplasm of basophilic megaloblast without vacuole. In addition to it, hemoglobin appeared in the nucleus and was localized among the meshes of the chromatin net work except in the site of nucleoli.

4. The hemoglobin at the sites of chromosomes in anaphase was photographed with the similar granulated feature like those in resting phase. With all of these findings, author's results agree with THORELL's; it is supposed that most intranuclear hemoglobin may be caused by its adhering to the chromosomes at the mitotic stage.

Author is much indebted to Professer M. MORI for his advice and encouragement.

\section{内 容自抄。}

家邹卵を $39 \pm 0.5^{\circ} \mathrm{C}$ で孵卵して, 卵黄囊造血領域の初期血島, 及び血流開始 直後の卵黄囊血管からの血液を材料にとった. Giemsa 染色, 及び May-GrünwaldGiemsa 染色で赤血球系細胞の発達段階を観察しながら，一方では石英スライド グラスに材料を塗抹した。塗抹した材料は 24 時間ホルマリン蒸気を作用して、へ モグロビン（以下 $\mathrm{Hb}$ と略記）をメト-Hbとなし，メタノール固定後 $408 \mathrm{~m} \mu$ の 単色光で Heme のを顕微分光写真法で撮影した。更に, Ralph 法で Hb 染色し た.

所見は次のようであった。

1. Primitive blood cell には Heme の吸光とHb の染出が認められない.

2. Promegaloblast では全細胞質に亘り, Heme の吸光が有意義の程度に均一に 認められるが, basophilic megaloblast 期になって核内に現れるその顆粒状の吸光 像は本期の細胞ではまだ認められない. Hb の染色像も同じ結果を示す。故に, $\mathrm{Hb}$ は初期から主として細胞質中で形成されるのであろう。

3. Basophilic megaloblast の細胞質内 Heme の吸光は前者より著しく増加する. 同時に，本期の細胞に於いて，初めて，顆粒状の Heme の吸光が核内に散在して 罗れる。然し核内の 1 丁至 2 ケの円形部位には吸光が認められない，恐くその位 置に核小体があるのであろう. Hb の染色標本も同じ結果を示す。 
4. 有糸分裂の中期から終期にある basophilic Megaloblast の Heme 吸光像では 染色体が直接細胞質内にあるにも拘らず，染色体の位置に静止核に見られるの之 同じ様な顆粒状の，その他の細胞質の部分の吸光度よりいくらか強い Heme の吸 光像がある. 故に，この所見と 3 及び 4 の所見から核内の Hb は細胞分裂時に染 色体に附着して取り込まれたものと推定せられた。

\section{References.}

Amano, S. : Ketuekigaku no kiso. (Jap.) 1948. - Astaldi, G. and his co-workers: Acta haematol. 9 (1953). - Carvalho, S. De : Acta haemat. 9 (1953). - Blood 10 (1955). Cole, P. A. and Brackett, F. S. : Rev. sci. Instr. 11 (1940). - Jensen, W.N. and his co-workers : J. Lab. a. clin. Med. 42 (1953). - Knoll, W. : Fol. haemat. 44 (1931). -Loele, W.: Münch. med. Wschr. 57 (1910). — Metcalf, W. K.: Blood 6 (1951). - Nagai, T.: Kessikiso no seiri to rinsho. (Jap.) 1958. — Nakao, K. : Saishin Igaku. (Jap.) 11 (1956). Nakao, K. and T. Nagai : Acta hematol. Jap. 21 (1958). -Sabin, F.R.: Contrib. Embryol. 9 (1920). - Seno, S. : Acta med. Okayama 11 (1957). - Acta hematol. Jap. 21 (1958). — Acta hematol. Jap. 18 (1955). - Sympos. Soc. cell. Chem. (Jap.) 8 (1958). - Seno, S. and his coworkers : Acta hematol. Jap. 20 (1957). - Slonimski, P.: Z. Zellforsh. 16 (1936). - Soret, F. L. : Arch. Sci. phys. nat. 61 (1878). - Sorenson, G. D. : Labor. Invest. 10 (1961). Storti, E.: Arch. Zoolog. Ital. 22 (1935). (quoted from Astaldi's paper). -Thorell, B.: Acta med. scand. Suppl 200 (1947). - J. Embryol. exper. Morph. 1 (1953). - Villa, L.: Arch. Path. Anat. Physiol. 42 (1930). -Walsh, R.J. and his co-workers: Science 110 (1949). -Wilkins, M. H. F. and Carvalho, S. De : Blood 8 (1953). 